\title{
FTIR-PCA analysis as an initial analysis to distinguish the origin of skin and leather
}

\author{
Ragil Yuliatmo $^{1^{*}}$, R. Lukas Martindro Satrio Ari Wibowo', Wisnu Pambudi', Sofwan Siddiq \\ Abdullah ${ }^{1}$, Thoyib Rohman Hakim ${ }^{1}$, Yuny Erwanto ${ }^{2}$ \\ ${ }^{1}$ Department of Leather Processing Technology, Politeknik ATK Yogyakarta, Jl Ateka No. 1, Bantul 55188, Indonesia \\ ${ }^{2}$ Department of Livestock Technology, Faculty of Animal Science, Jl. Fauna no. 1, Sleman 55281, Indonesia \\ * Coresponding author. +62 8995151003 \\ e-mail: ragilyuliatmo@atk.ac.id
}

\begin{abstract}
Leather products are parts of daily fashion in Indonesia, such as bags, shoes, jackets, and gloves. Adulteration of raw materials for leather products can occur if there are no labels on these products. Various methods such as PCR, GC-MS, HPLC, and FTIR have been carried out to distinguish the origin of leather products. The FTIR method is known as an easy and inexpensive method to use. The objective of this study was to evaluate the capability of FTIR spectroscopy and Principle Component Analysis (PCA) for lipid identification and initial analysis to distinguish the original materials on leather products. Lipid extracts obtained from the various skin were scanned using an FTIR spectrophotometer at $4000-450 \mathrm{~cm}^{-1}$. It resulted in spectral differences in several wavenumbers (3000-2800 $\mathrm{cm}^{-1}$ and $1200-1000 \mathrm{~cm}^{-1}$ ). The same result is also found in lipid spectra from leather product extraction. The FTIR spectroscopy and PCA can differentiate pigskin and goatskin through specific peaks in infrared spectra. This can be used as an initial analysis on determining the existence of skin adulteration in leather products. This study is prospective to be continued by chemometrics as quantitative analysis.
\end{abstract}

Keywords: FTIR spectroscopy, goatskin, leather products, pigskin, PCA analysis.

\section{INTRODUCTION}

The tanning and leather industry never stops innovating to meet the needs of consumers in line with the development of fashion and automotive. The Indonesian Ministry of Industry explained that there was an increase in the trend of exports of leather goods in 2016. An increase in the trend of footwear exports for daily use was $10.26 \%$, field engineering shoes/industrial use was 9.54\%, and goods from leather and artificial leather for personal use by $6.36 \%$. Domestically, the industry growth of leather, leather goods, and footwear increased by $18.78 \%$. An increase in the product information did not accompany these increases. The information for the customer about the authentication of the origin of materials on leather products is limited. Determining the origin of product material is one of the main issues in the industrial sector, not only for producers but also for consumers (Erwanto et al., 2016). The detection of the original material of the products is necessary for consumer protection as well as for various reasons, such as religious reasons. For Muslim and Jewish communities, the use of pork is prohibited by their religion. Recently, leather product manufacturers in some countries choose to use pork skins as a substitute for other skins, because of their low cost and easy access (Aida et al., 2007). The identification of the origin of the skin on the leather products is important for the customer, and it needs to be proven scientifically. Identification of origin material on the product has often been made on food products. Detection of rat meat in beef sausage (Pebriana et al., 2017), porcine contamination in Dendeng (Maryam et al., 2016), and lard adulteration in Rambak crackers (Erwanto et al., 2016) were analyzed by various methods. Fourier-Transform Infrared (FTIR) spectroscopy has been known as one method to identify the origin of material based 
on the lipid profile. According to Muttaqien et al. (2016), this method that was combined with chemometrics, such as PCA, is easy, fast, and inexpensive. Research on identifying the origin of material on the skin has never been studied. This research was aimed to develop the utilization of FTIR spectroscopy combined with PCA as an initial analysis to distinguish skin materials.

\section{MATERIALS AND METHODS Lipid Extraction}

Lipid extraction using the Soxhlet method was performed according to AOAC (2012). Pigskin, goatskin, pigskin leather, and goatskin leather were obtained from the traditional market and leather distributors. $50 \mathrm{~g}$ of samples in filter paper were placed into the Soxhlet apparatus (Iwaki SOXH-SET, Indonesia) and added 250 $\mathrm{mL}$ of $\mathrm{n}$-hexane as an extracting solvent. The extraction was conducted for $8 \mathrm{~h}$ at $70{ }^{\circ} \mathrm{C}( \pm 50$ cycles). Anhydrous sodium sulfate is added into the lipid extract, mixed, filtered, and evaporated until the solvent was completely removed. The resulting lipid fraction was then used for FTIR spectral measurements.

\section{FTIR Spectral Measurements}

Extracted lipids were located in attenuated total reflectance (ATR) crystal at $25^{\circ} \mathrm{C}$. The spectrum was obtained in the wavenumbers region of $4000-450 \mathrm{~cm}^{-1}$ using an FTIR spectrophotometer (Perkin-Elmer, Singapore).

\section{Data Analysis}

The spectrum from FTIR spectral measurement results was analyzed descriptively by Principal Component Analysis (PCA) using The Unscrambler X 10.4 (CAMO Software AS).

\section{RESULTS AND DISCUSSION Lipid Extraction}

Raw skin and leather have been extracted by the Soxhlet method and using n-hexane as solvent. $\mathrm{N}$-hexane is suitable for use in the extraction of fat on the skin. It caused n-hexane is nonpolar, however fat which is also non-polar, and n-hexane is quickly evaporated because it has a low boiling point of $69^{\circ} \mathrm{C}$ (Erwanto et al., 2016). The extraction of fat from all samples produced yellowish and thick oil, but specifically in goatskin fat produces oil that is quickly frozen at room temperature, while others are not.

\section{FTIR Analysis}

The FTIR spectra of lipid obtained from skin and leather samples have similar profiles. Figure 1 shows lipid spectra of pigskin, goatskin, pigskin leather, and goatskin leather lipid. Infrared spectra are read at $4000-450 \mathrm{~cm}^{-1}$, which is the middle region. Many molecules have a strong absorbance in the middle infrared region. Many types of samples including liquids, gases, powders, polymers, solids, semisolids, organic, inorganic, biological substances, pure substances, and mixtures can be measured in the middle region

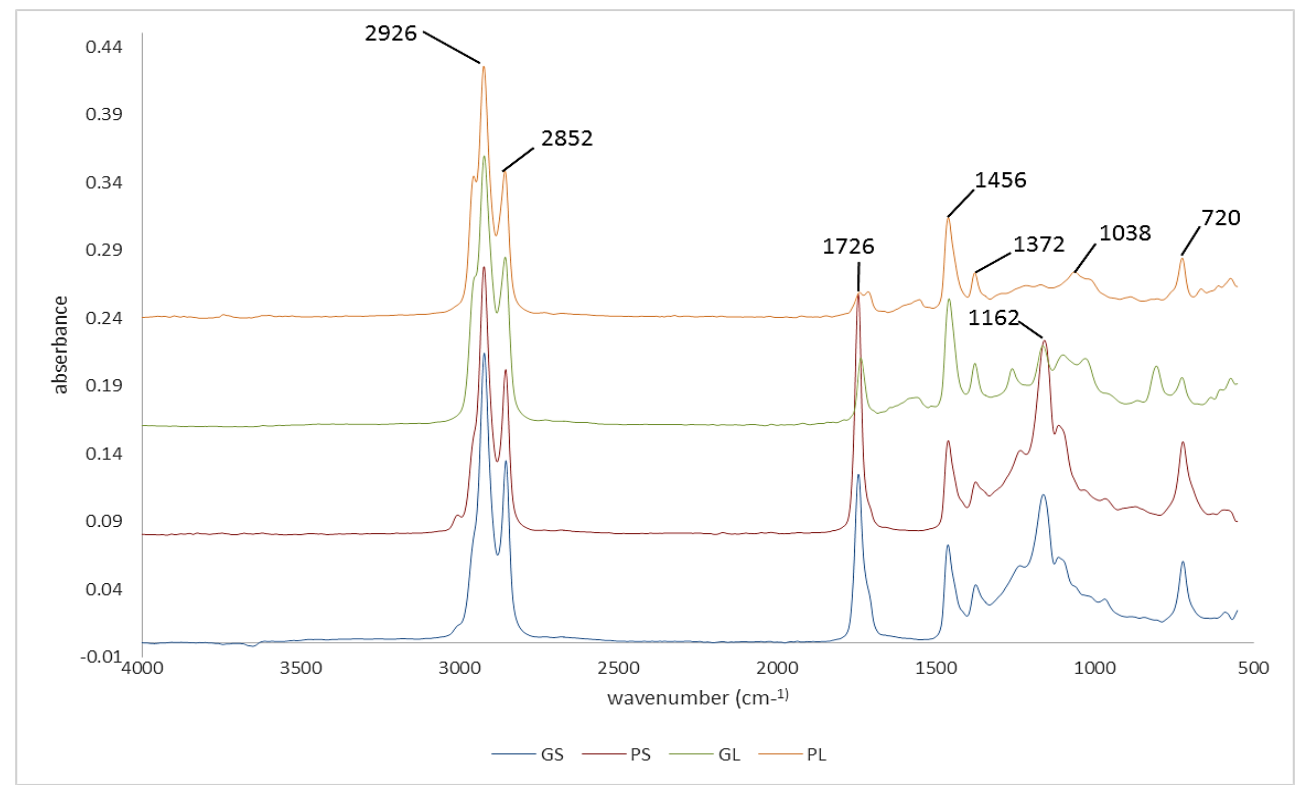

Figure 1. FTIR spectra of skin and leather samples. 
Table 1. The wavenumbers of FTIR spectra of skin and leather lipid samples and the corresponding functional groups' vibration.

\begin{tabular}{cc}
\hline Wavenumber $\left(\mathrm{cm}^{-1}\right)$ & Type of bending and vibration \\
\hline $3000-2840$ & $\mathrm{C}-\mathrm{H}$ stretching \\
$1750-1735$ & $\mathrm{C}=\mathrm{O}$ stretching (ester) \\
$1740-1720$ & $\mathrm{C}=\mathrm{O}$ stretching \\
$1465-1450$ & $\mathrm{C}-\mathrm{H}$ bending \\
$1390-1380$ & $\mathrm{C}-\mathrm{H}$ bending \\
$1260-1234$ & $\mathrm{C}-\mathrm{O}$ stretching (ester) \\
$1202-1124$ & $\mathrm{C}-\mathrm{O}$ stretching \\
$808-716$ & $\mathrm{C}-\mathrm{H}$ bending \\
\hline
\end{tabular}

(Rohman et al., 2017).

The compilation of wavenumbers from each peak in the FTIR spectrum of the skin and leather samples and the related functional group vibrations are shown in Table 1. Basically, functional groups of skin and leather almost similar, but there is a bit of difference in peak intensities at around 1200 and $3000 \mathrm{~cm}^{-1}$. The skin samples at around 1200$1000 \mathrm{~cm}^{-1}$ there is a peak while the leather samples are not. It was suspected that due to the existence of natural fat in the skin. Degreasing is a process for decreasing the natural fat in raw skin during tanning (Covington, 2009). Pig and goat lipid samples (skin and leather) also almost similar but at around $3000-2800 \mathrm{~cm}^{-1}$ and $1200-100 \mathrm{~cm}^{-1}$ there are slightly different peak intensities. Therefore, optimization of FTIR spectra by selecting the wavenumbers region and spectral treatment was carried out to differentiate between pig and goat
(Riyanta et al., 2020).

\section{Principal Component Analysis}

Principal Component Analysis (PCA) is an analysis that is often used to be applied to find differences in samples that have close similarities based on absorbance values (Riyanta et al., 2020). Figure 2 shows two loading plots from spectra at wavenumber $3000-2800 \mathrm{~cm}^{-1}$ (A) and 1200-100 $\mathrm{cm}^{-1}$ (B). Based on loading plots, the samples spread in a different area. Loading plot A can separate the sample into two areas, the upper area consists of pigskin leather (PL) and goatskin leather (GL), while the bottom area consists of pigskin (PS) and goatskin (GS), although the distance between each sample is far. Loading plot B shows a better sample distribution by separating the sample into three areas. Pig and goat samples (skin and leather) are in different areas. Even

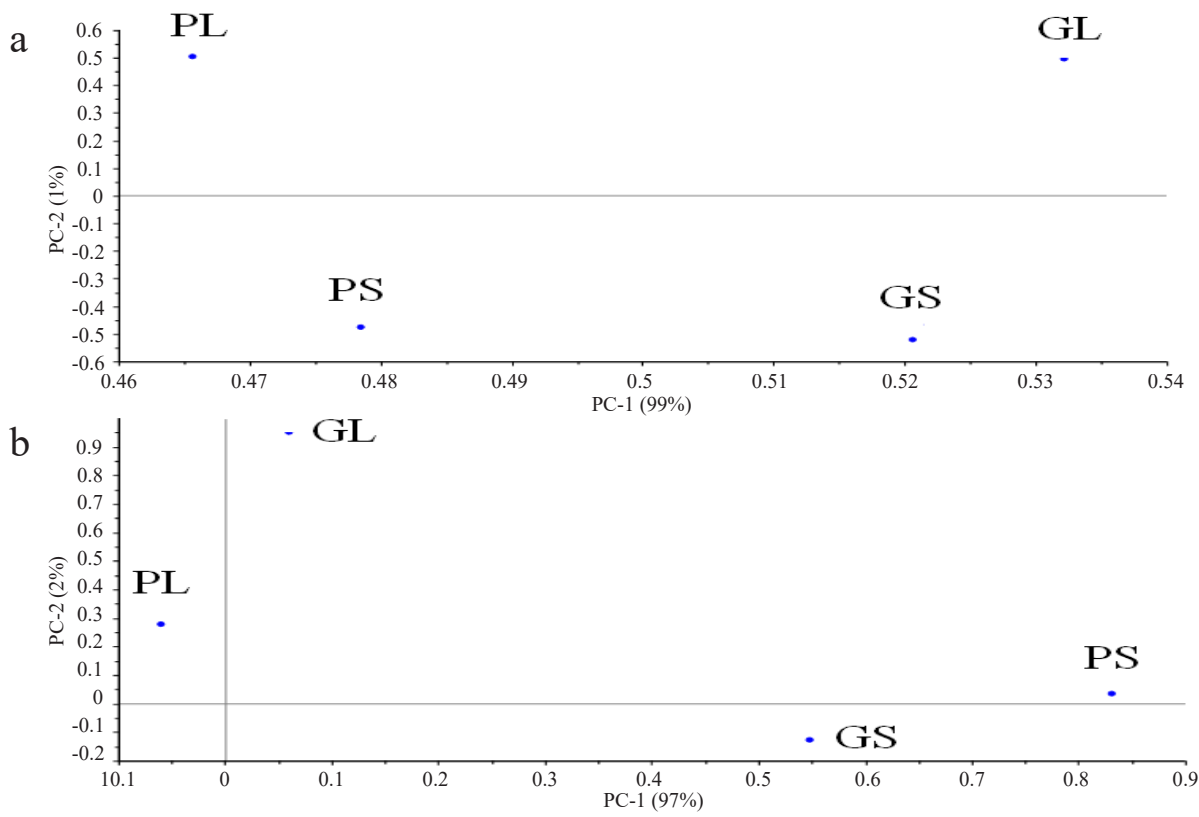

Figure 2. The loading plot of PCA for the classification of pigskin (PS), goatskin (GS), pigskin leather (PL), goatskin leather (GL) at wavenumber $3000-2800 \mathrm{~cm}^{-1}$ (a) and $1200-100 \mathrm{~cm}^{-1}$ (b). 

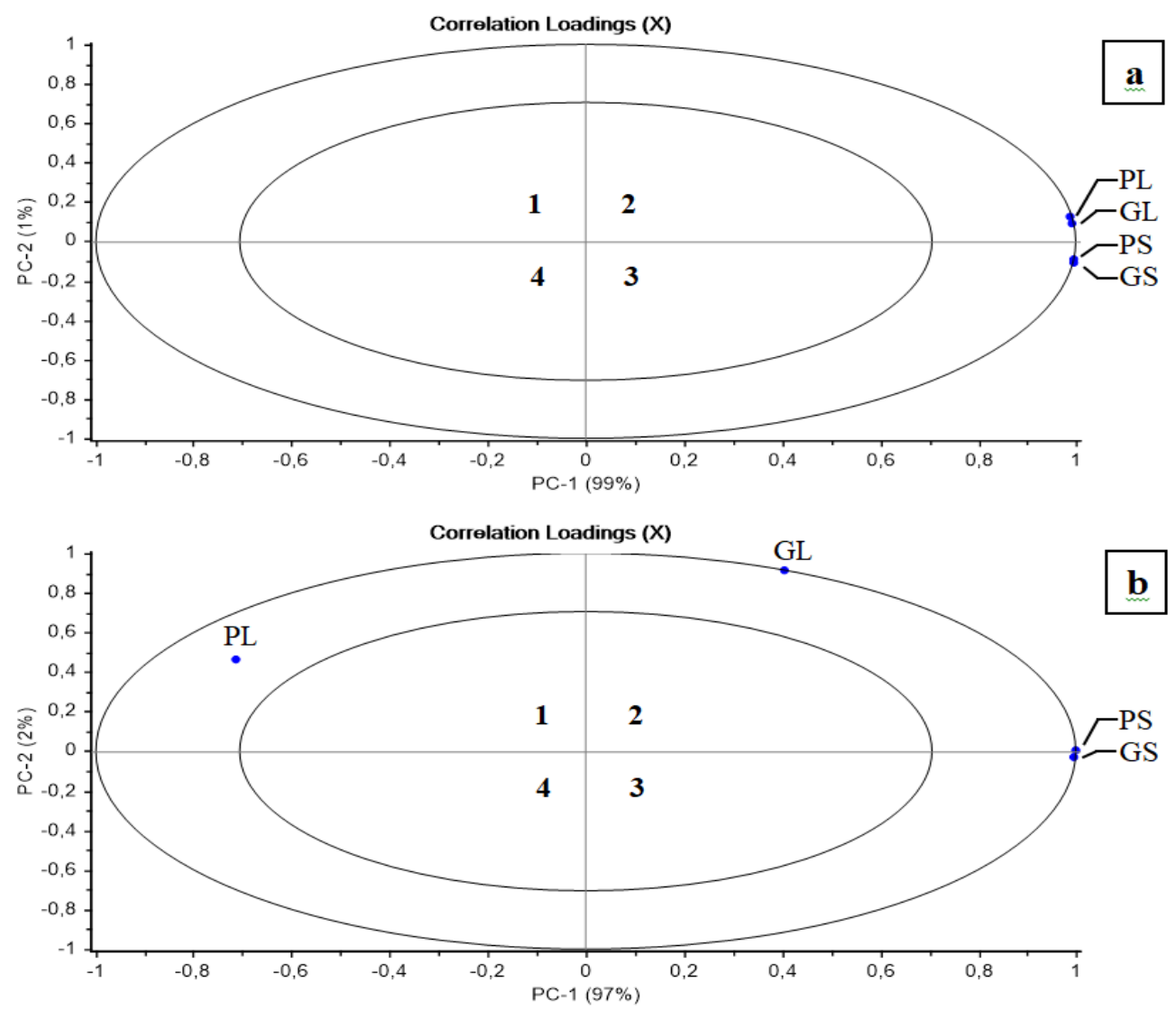

Figure 3. The correlation plot from samples in range $3000-2800 \mathrm{~cm}^{-1}$ (a) and $1200-100 \mathrm{~cm}^{-1}$ (b).
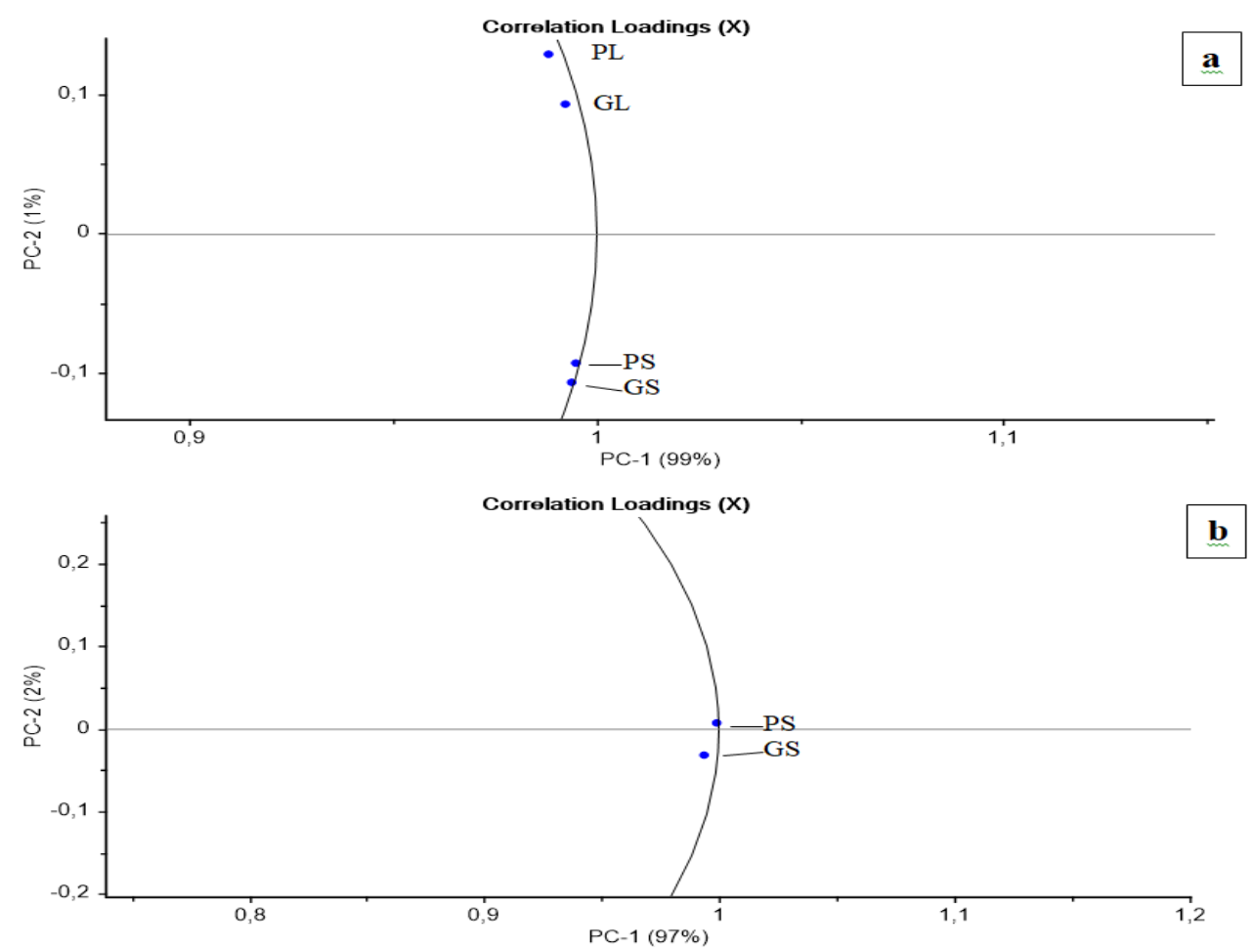

Figure 4. Enlargement of correlation plot (region $2 \& 3$ ) from samples in range $3000-2800 \mathrm{~cm}^{-1}$ (a) and $1200-100 \mathrm{~cm}^{-1}$ (b). 
though PL and GS are in the same area, they are on a long-distance. These states are supported with a correlation plot in Figures 3 and 4. Correlation plot A shows the correlation among the samples at wavenumber $3000-2800 \mathrm{~cm}^{-1}$, while B shows at $1200-100 \mathrm{~cm}^{-1}$. Based on the correlation plot, the wavenumber at $3000-2800 \mathrm{~cm}^{-1}$ separated samples closer, than the wavenumber at 1200 $100 \mathrm{~cm}^{-1}$. Correlation plot $\mathrm{B}$ can well separate pigskin and goatskin leather however pigskin and goatskin show a closer position to each other. Even though, magnification showed these samples (PS and GS) separated with a line between two areas. Classification in the wavenumber range at 1200-100 $\mathrm{cm}^{-1}$ corresponds to results Erwanto et al. (2016), Muttaqien et al. (2016), and Rohman et al., (2017), which can distinguish between lard and other species of fat, such as beef or buffalo fat.

\section{CONCLUSIONS}

The use of FTIR Spectroscopy method and analysis by PCA can be applied and developed to initial analysis for distinguishing and classifying the origin skin (pigskin and goatskin) in leather products (pigskin and goatskin leather). Analysis results using PCA from spectra samples in wavenumber at $1200-1000 \mathrm{~cm}^{-1}$ showed separated samples better than wavenumber at 3000-2800 $\mathrm{cm}^{-1}$.

\section{ACKNOWLEDGEMENTS}

The authors would like to thank Ministry of Industry and Polytechnic ATK Yogyakarta for financial support during this research via Research Grants UP2M Polytechnic ATK Yogyakarta.

\section{REFERENCES}

Aida, A. A., Che Man, Y. B., Raha, A. R., \& Son, R. (2007). Detection of pig derivatives in food products for halal authentication by polymerase chain reaction-restriction fragment length polymorphism. Journal of the Science of Food and Agriculture, 87(4), 569-572. https://doi. org/10.1002/jsfa.2699
AOAC (Association of Official Analysis Chemists). (2012). Official Methods of Analysis of AOAC International (19 $9^{\text {th }}$ ed.). Maryland, USA: AOAC.

Covington, A. D. (2009). Tanning chemistry: The science of leather. Cambridge, UK: RSC Publishing.

Erwanto, Y., Muttaqien, A. T., Sugiyono, Sismindari, \& Rohman, A. (2016). Use of fourier transform infrared (ftir) spectroscopy and chemometrics for analysis of lard adulteration in "rambak" crackers. International Journal of Food Properties, 19(12), 2718-2725. https://doi.org/10.1080/10942912.20 16.1143839

Maryam, S., Sismindari, Raharjo, T. J., Sudjadi, \& Rohman, A. (2016). Determination of porcine contamination in laboratory prepared dendeng using mitochondrial D-loop686 and cyt b gene primers by real time polymerase chain reaction. International Journal of Food Properties, 19(1), 187-195. https://doi.org/10.1080/10942912.2015 .1020434

Muttaqien, A. T., Erwanto, Y., \& Rohman, A. (2016). Determination of buffalo and pig "rambak" crackers using FTIR spectroscopy and chemometrics. Asian Journal of Animal Sciences, 10(1), 49-58. https://doi.org/10.3923/ ajas.2016.49.58

Pebriana, R. B., Rohman, A., Lukitaningsih, E., \& Sudjadi. (2017). Development of FTIR spectroscopy in combination with chemometrics for analysis of rat meat in beef sausage employing three lipid extraction systems. International Journal of Food Properties, 20(2), 1995-2005. https://doi.org/10.1080/10942912.2017.1361969

Riyanta,A.B., Riyanto, S., Lukitaningsih,E., \& Rohman, A. (2020). The employment of fourier transform infrared spectroscopy (FTIR) and chemometrics for analysis of candlenut oil in binary mixture with grape seed oil. Food Research, 4(1), 184190. https://doi.org/10.26656/fr.2017.4(1).279

Rohman, A., Himawati, A., Triyana, K., Sismindari, \& Fatimah, S. (2017). Identification of pork in beef meatballs using fourier transform infrared spectrophotometry and real-time polymerase chain reaction. International Journal of Food Properties, 20(3), 654-661. https://doi.org/10.10 $\underline{80 / 10942912.2016 .1174940}$ 
